\title{
Theoretical approaches to researching learning spaces
}

\author{
Leon Benade \\ Auckland University of Technology \\ lbenade@aut.ac.nz
}

Key words: spatiality; learning environments; ILE; flexible learning spaces; educational innovation; Lefebvre

\begin{abstract}
Contemporary learning environment designs bring to life schools featuring loose fitting, flexible layouts that upset the stable certainty of the four-walled classroom. This article presents the argument that adopting a theoretical approach to researching the role of spatiality and space in relation to innovative building design in education will enable insights otherwise not possible, and, in the process, enhance the available store of knowledge and understanding. A review of a sample of published research that considers innovative learning environment design suggests that robust theoretical approaches are eschewed in favour of instrumental research often concerned with the role played by building fabric or with psychosocial responses to the surrounding learning environment. To adopt an alternative, theoretical perspective that privileges the concept of 'space' in education, it is first important to understand developments in spatiality. Exemplifying one such theoretical approach to questions of spatiality in education, Lefebvre's spatial theory is applied to the recent development of FLS and ILE in New Zealand, though several optional theoretical approaches to spatiality are suggested as open to education researchers.
\end{abstract}

\section{Introduction: A review of recent learning environments research}

The four walled classroom offered certainty in the twentieth century, whereas the loose fitting, flexibly designed learning environment, increasingly apparent across the school system in New Zealand and well beyond, has upset this stable certainty. These modern, bespoke facilities, it has been suggested, can motivate students, inspire them, and generally better meet their expectations as ' $21^{\text {st }}$ century learners' (Imms, 2016; Ministry of Education, 2011; Nair, 2014). The currently-held view of the New Zealand government is that the building and upgrading of school facilities should simultaneously support student success and wellbeing and support each school's unique vision for teaching and learning (Hipkins, 2018; Ministry of Education, 2020). In recent years, a widening scholarship has emerged in Australasia and internationally, in relation to the design and provision of innovative educational facilities (examples include Benade, 2017a; 2017b; 2019a; b; Benade et al., 2018; Byers et al., 2018; Campbell, 2020; Daniels et al., 2017; Imms et al., 2016; Charteris \& Smardon, 2018; 2019; Charteris et al., 2017; Sigurðardóttir \& Hjartarson, 2016; 2018).

Learning environments research is not a new field, though studies from the 1970s and 1980s focussed on 'class climate' (Alansari \& Rubie-Davies, 2020). The studies mentioned above are examples of scholarly interest in architectural developments in 
education facilities of the kind denoted by terms such as 'Modern/Flexible/Innovative Learning Environments' or 'New Generation Learning Spaces'1. What seems apparent, however, is that rigorous theoretical and conceptual framing of contributions to the field of learning environments research has been sparse or patchy at best, with some exceptions (amongst those being in the list above). I have attempted to validate this contention by reviewing a sample of recently published research, internationally, in the European context, in Australasia, and finally, Aotearoa New Zealand. My primary focus was only those articles specifically related to the built learning environment, or studies that explored the relationship between the built environment and the users of those environments. A secondary focus was to establish the role of theory or robust conceptual frameworks in the selected studies. These parameters are significant, as the prompt for this article is to develop the relevance of theoretically informed analyses of the steady development of bespoke designs across the education spectrum, with specifically emphasis on the spatial dimension of the built environment of schools. Secondly, because of my own underlying theoretical position in this article (and elsewhere), that the building does matter (because it is in dialectical relation to its occupants, whose practices are influenced by the built environment), relevant studies selected were those that consider this dialectical relationship.

To ensure a manageable 'data set', five publication sources were selected, demonstrating a range of examples of published research under the broad umbrella of 'learning environments', produced in multiple geographic locations, that followed diverse theoretical, conceptual, and/or methodological pathways. The examples were:

- Learning Environments Research, a Springer published, international journal (see https://www.springer.com/journal/10984), considering all issues published 2018-2020;

- A 2017 Special Issue of the European Journal of Education, under the subject of Participatory design of (built) learning environments (see https://onlinelibrary.wiley.com/toc/14653435/2017/52/3)

- The 2017 and 2018 iterations of the published Proceedings of the Melbournebased Innovative Learning Environments and Teacher Change (ILETC) project 'Transitions' symposium for graduate and early career researchers (see http://www.iletc.com.au/publications/proceedings/)

- A 2017 'Leading ILE in New Zealand' Special Issue of the Journal of Education Policy and Practice (see https://nzeals.org.nz/jelpp/jelpp-volume-32-1-jun2017/)

- A 2017 'Modern Learning Environments' Special Issue of Educational Philosophy and Theory (see https://www.tandfonline.com/toc/rept20/49/8)

My review of three years of publication of Learning Environments Research (20182020: 73 articles) found only thirteen articles specifically related to the built learning environment, or that explored the relationship between the built environment and the users of those environments. Remarkably few qualitative studies were noted across the three years, and of the selected articles, only six had any explicit theoretical or conceptual framing, often not to a robust level. To the extent there was evidence of

\footnotetext{
${ }^{1}$ In keeping with my research interventions to date, the built environment where teachers and students work is referred to as 'Flexible Learning Space/s' (FLS), and 'Innovative Learning Environment' (ILE) is used to denote a whole school that is built in flexible, non-traditional style.
} 
any theoretical or conceptual motif across the 73 articles, this was seen in the interest of authors in psychosocial dimensions, often linked to 'classroom climate', which in turn are heavily focussed on teacher-student interactions and the influence of these on student perceptions, behaviours and achievement. Among the thirteen relevant studies, the role of the material building fabric, furniture, and technological apparatus in affecting student psychosocial response was emphasised.

The European Journal of Education special issue consisted of five original articles, an editorial and two short commentaries on the articles. Of the articles, all of which were qualitative, only two had any obvious theoretical framing or analysis, though most attempted to use forms of design modelling to be applied to their studies of participation. Overall, the issue took a pragmatic and instrumentalist approach to the question of participation in the design of learning environments. The underlying approach was positivistic, less interested in critique and theory and more interested in description and 'what works'.

The 2017 Melbourne iteration of Transitions consisted of twelve contributions, by higher research degree students, recent graduates, and early career researchers. The issue included seven presentations whose authors were guided by theoretical concerns. Most of the studies were qualitative, though two used mixed-methods research (MMR). The five that did not reflect a theoretical or strong conceptual basis included the two MMR projects. The focus of all these studies was on the built learning environment, in line with the intent of the larger research team they are allied to. The 2018 iteration of Transitions amalgamated three international events. It included 29 presentations by higher research degree students, recent graduates, and early career researchers. Only five presentations articulated any theoretical concerns. Most of the studies were qualitative, though four used MMR, and one was quantitative. Two of the five that did reflect a theoretical or strong conceptual basis were MMR projects. One of these five - the only one in either 2017 or 2018 - had a wholly conceptual or theoretical approach. The focus of all these studies were either on the built learning environment, or the relationship between the built environment and other aspects of pedagogy.

The 2017 special issue of the New Zealand-based Journal of Education Policy and Practice contained eleven articles and an editorial. The articles included reports of two MMR studies, neither which took up a conceptual or theoretical position, though one was strongly methodological; all the others were qualitative. Overall, this issue offered little by way of robust theoretical or conceptual analysis of the bespoke building phenomenon. Its approach was skewed towards practitioner reflections and schoolbased inquiries, such that the issue assumed the mantle of professional inquiry, with six of the eleven articles specifically being practice-based. Of the remaining five, only two attempted to take seriously the value of conceptual frameworks or theoretical ideas: one to develop a visual heuristic through which to mediate developing conceptions of the Innovative Learning Environment (ILE) concept; the other to use sociological structuration theory to interpret one school's innovative approach to curriculum and organisation.

A 2017 'Modern Learning Environments' special issue of Educational Philosophy and Theory contained six articles and an editorial. As may be expected of articles published by this journal, all articles had conceptually robust theoretical or 
philosophical bases of analysis. The authors had responded to a call provoked by the view of American architect, Prakash Nair, that the 'classroom is obsolete' (2014). Two articles did not draw on empirical studies-one engaging in policy analysis and policy comparison, the other in discourse analysis, specifically critiquing the Nair statement. The other four reflected directly on the respective authors' empirical studies of ILE, in New Zealand and Australia. They provided accounts of robust qualitative methodologies, and couched their results in various conceptual or theoretical contexts, ranging from new materialism to theories of spatiality.

An abiding sense of much of the material reviewed here (136 original articles) is a general lack of attention to crafting studies, or the analysis of studies, around robust theoretical or conceptual frameworks of understanding. Where these frameworks are in evidence, to greater or lesser extent, they are dominated by approaches that reduce the complexities of the lived experience of innovative or flexible learning spaces to psychosocial responses to external stimuli or they seek to impose instrumentalised 'throughput-output' thinking, based on a realist ontology. Typically, such thinking, highly pervasive in much current educational discourse, focuses only on 'what works' approaches, and overemphasises human control of environmental factors.

Thirteen years ago, Gulson and Symes (2007) noted a spatial turn in social theory that, they argued, had not been fully taken up in education. They acknowledged evidence of "incipient theories of space pertaining to education" (p. 97). More recently, Biesta (2018) remarked on the 'spatial turn', but the evidence from this snapshot of recent learning environments scholarship suggests that spatial theorising is still not widespread in educational discourse, and that spatial theories in education remain incipient. With those critiques in mind, and to further consider the wider implications of space, I will first provide a theoretical framework for thinking about spatiality in general, setting the stage for some thinkers whose theories are pertinent to thinking about FLS and ILE. I then move to the education context, asking, "why is space important in education research'? Finally, I apply Lefebvre's triadic conceptualisation (1991) of space to the current trend to innovative school building design in Aotearoa New Zealand.

\section{Theories of spatiality}

Foucault (2008), invited to speak to an architectural audience in 1967, argued that history was no longer in the ascendant, asserting that space and spatial considerations had come of age. This comment alludes to a theoretical and philosophical divide that had opened within Western Marxism exposing the absence of rigorous spatial considerations by Marx-indeed, argued Soja (1989), Western Marxism had developed an anti-spatial tradition. At best, it came to treat space as a container, or as a backdrop, while at worst, it saw in space the spectral threat of fetishisation. For structural Marxism particularly, economic causality came to be regarded as the only mode of analysis, mediated by time, thus consigning space to irrelevance (Soja, 1989).

The discipline of Geography, intimately concerned with matters of space, reflected these tensions. The trend in geography up to the 1960s, Smith (1990) indicated, was to regard space as 'absolute' (space as existing independently). This conceptualisation of space was an abstraction that had developed over time in tandem with Western philosophical thought. Ancient conceptualisations had imagined space 
and place as coterminous concepts, in which social relations formed the basis of people's identification with the land and nature (Smith, 1990). The steady abstraction of space paralleled that of commodity exchange, bifurcating space and society, severing the traditional relationship with place. The 1960s positivistic turn in geography (Massey, 1984/1995) led, suggested Smith (1990), to an interest in 'relative space' (space being defined relative to material phenomena). By the 1970s, scientific approaches to spatiality were being supplanted by a focus on social processes occurring over space, though Massey (1984/1995) suggested that, at least initially, the social and the spatial continued to be treated as discrete elements. Lefebvre's iconic 1974 work, La production de l'espace, translated into English in 1991, as The Production of Space, spurred critical geographers and urban theorists to reimagine the relationship between the social and the spatial. Lefebvre deeply influenced Soja (1985; 1989), and together, their work generated significant interest by their triadic conceptualisations that emphasised the dialectical relations among conceptualisations of space, sociality and temporality, seeking to show that space is a human construct.

Despite these advances in theorising spatiality, however, Smith (1990) argued that space continued to be considered an unproblematic absolute concept from a capitalist perspective. Soja (1989) had suggested a contrary perspective, though, suggesting that space had assumed greater significance through globalisation and production outsourcing to low-wage economies as legislative changes in First World states improved workers' conditions. Soja's insightful analysis of spatiality, that I will now consider, provides a scaffolded segue to understanding Lefebvre's unique approach to spatiality.

As outlined by Soja (1989), spatiality is both the outcome and method of social relations and social structures. By arguing for social life as producer and a product of spatiality, Soja was drawing attention to the dialectical relationship between the two, and the likelihood of friction in this relationship. Spatiality is dynamic and characterised by a daily struggle to maintain the status quo or to upset it. The playing out of this dialectic gives rise to questions of primacy in the ongoing relationship between people and space. Soja suggested that these questions would be fundamental to social theory. He argued for a materialist interpretation of space, which had been, at least until the 1980s, largely ignored in theory. He followed Lefebvre closely in asserting the view that a social spatiality unhinges the traditional mental-physical bifurcation, and in the process, transforms those physical and mental spaces (1989). These spaces must be influenced by the social-indeed, produced and reproduced by the social. Conversely, social space cannot be independent of physical and conceptual space (1989). Yet, attempts to apply empirical measures to spatial phenomena led to opaqueness and myopia. These approaches mask the socio-political reality of space, replete with agency, tensions, contradictions, and conflicts. An alternative form of myopia is to abstract space and render it in mental terms only. Now, space becomes subject to mental ordering.

Soja accused Marxists of failing to grasp the significance of space, only seeing space as imposed on social relations, and both as subject to temporal determination. Soja presents instead a dialectical understanding of the relationship between the structures of space and society - there is no imposition of the one on the other. From this dialectic arises the "theoretical keystone for the materialist interpretation of 
spatiality...[namely]...that spatial structures and relations are the concrete manifestations of social structures and relations evolving over time, whatever the mode of production." (1989, p. 127).

Although chronologically reversed here, Soja's (1989) interpretation of spatiality (which draws heavily on Lefebvre) provides a scaffolded entry to the complex interpretation provided by Lefebvre in his 1974 La production de l'espace, translated to English in 1991. Lefebvre famously 'detonated' the mental-social or mental-material bifurcation that had arisen from the steady abstraction of space in Western thinking, which gave rise to the idea of space as an empty container waiting to be filled (1991). He challenged the temporal and historicist framework developed by Marx, in which social relations are regarded as determined or at least shaped by history, and in which space has no role. Yet, he was interested to understand why capitalism endures, and argued that space is central to the answer-but it is an answer difficult to grasp because space as a concept, he believed, was both novel and complex (1991). Space was the location for three productive forces: i) biological (the family); ii) labour power (the working class); and iii) social relations (what makes a society distinctively what it is, eg capitalist or feudal) (1991, p. 32). It is the organisation of space that supports the on-going production of the dominant system of social relations (ie capitalism).

Instead of adhering to narrow Marxist conceptions of economic and temporal determinism, Lefebvre emphasised instead the phenomenology of everyday life. He thus argued that space is socially produced, and that social relations are affected by space. Lefebvre wanted to show space as both produced and experienced; seeking to recognise a unity in spatiality by rejecting differentiation and fragmentation, which obscure a full understanding (Elden, 2004a; Merrifield, 2006). Space, for Lefebvre, is produced in two ways, through mental conceptions, and through social relations. There is, however, a critically significant third element between conception and perception, namely lived space. The conceptual triad, l'espace perçu, conçu, vécu, that is, spatial practice, representations of space and representational space, blend physical, mental and social space in the production of space:

- spatial practice (perceived space) requires a deciphering of real space in order to make choices and act, thus aims to guarantee a level of competence and level of performance;

- representations of space (conceptualised space) are communicated through designs and plans. This space represents the knowledge of space;

- representational space (lived space) is the felt experience of real places and spaces. It is dynamic and conveys rich meaning through symbol.

Table 1 (below) displays the triad in a form that brings together the multiple labels Lefebvre and others have applied to the model.

Place Table 1 here.

Table 1: Lefebvre's Triadic Conceptualisation of Space (after Lefebvre, 1991).

A cursory literature search reveals how the complex triad is unknotted in various ways while inspiring applications across a range of fields, including the urban built environment (Baydar et al., 2018), the development of places and spaces to enhance 
the democratic process (Jenlink, 2007), the school-yard/prison-yard nexus (Krueger, 2010), and the organisational analysis of theatre (Watkins, 2005). The complexity underlying this complicated triad is challenging to grasp-not least because Lefebvre's explanations sometimes seem contradictory. He did provide one helpful analogy, however, with the human body (see 1991, p. 40). Here he described the perceived as social practice (think of this as custom), which presupposes specific uses for various parts and organs of the body. Thus, hands may be considered as aids to friendship or appropriate to place on a table, whereas it may be considered rude and insulting to place feet or rear-ends on tables. Representations are conceptions of the body, contained in textbooks and diagrams, but sometimes influenced by ideology (such as misinformation regarding causes or treatments). The complex ways in which the body interacts with the world is its lived experience.

Unfortunately, Lefebvre's explanation of lived in the bodily analogy does not clearly establish a link to the representational. There is, however, some clarity to be derived from the interpretations of lived spaces in the notable analyses of Lefebvre by Elden (2004b) and Merrifield (2006). These authors interpret lived spaces as spaces of representation, rather than representational spaces. Thus, following Lefebvre's bodily analogy, lived experience can be taken as the way the self, the body, makes sense of the world to itself, and its own experience of the world. One way of conveying this sense-making is through attributing symbolic value to space. As Elden (2004b) has suggested, this is space that is real and imagined, while for Merrifield (2006, p. 110), it is "the café on the corner, the block facing the park, the third street on the right after the Cedar Tavern, near the post office...[spaces that] don't involve too much head [because] they're felt more than thought." Nevertheless, it is evident that lived and perceived space may easily be confused.

This substantive theoretical discussion of spatiality provides tools and language for thinking about space differently than simply as the ubiquitous background that teachers (and education scholars) may take for granted. The development of FLS and ILE in Aotearoa New Zealand and internationally has considerable implications for teaching and learning practice, as a range of research can already testify (such as the studies mentioned in the Introduction). Making sense of this reality, must, however, go beyond descriptively documenting the performance of building fabric or attitudes of teachers. Adopting a critical, theoretic attitude to the changed built environment of educational institutions provides alternative and illuminating insights. While regarded by some as obscure and unsuited to considerations of practical issues, a theoretic attitude and approach can challenge taken-for-granted issues or phenomena by treating them as problematic. Critical frameworks support interpretations of human experience and raise questions that would otherwise never see the light of day. Theory provides a language to name practice and by application is able to bridge the gap between theory and practice. Application of the theoretical insights of spatial thinking to education can raise the discussion of FLS and ILE beyond taken-for-granted discourse, as will be illustrated in the final stanza of this article. First, however, it is relevant to ask why considerations of space are relevant to educational research of ILE and FLS.

\section{Why is space important in education research?}


Educational spaces are like the air we breathe-that is, their existence is unremarkable, merging into the background. At a common-sense level, teachers in FLS or ILE might speak of their newly minted bespoke facilities in such terms as 'shared space', 'collaborative space', or, as in this article, 'Flexible Learning Space'. Thus, the noun, 'space' has acquired a taken-for-granted everydayness that places it beyond question. Newton (2009) offered three reasons why space would not matter to teachers-space is not part of formal education research and thought; the classroom (the physical space of work) is a ubiquitous presence in teachers' lives; and although they believe they control their spaces, teachers do not recognise its influence on their practice. While I agree somewhat with Newton's final point, by now it will be evident to teachers working in (or about to work in) FLS, that space certainly does influence their practice (or at least their views on practice). In research terms, as I have indicated earlier, questions of space seem frequently to be reduced to instrumental concerns with building performance, possibly because space continues to be understood by many education researchers as ontologically objective. This is despite the collective influence on geography and critical social studies of the work of Lefebvre (1991); Massey (1984/1995; 1985); Smith (1990); and Soja (1989). Thus, the critique of Gulson and Symes (2007), and later of Blackmore et al. (2011) that studies of the built place of learning have limited their focus to the performance of building fabric, seem to hold true, more than a decade on, as indicated by the earlier overview of recent learning environments research. A revised theoretical rigour towards questions of space does not need to concentrate only on these theorists who privilege the socio-cultural or socio-political dimension of spatiality. Other approaches to spatiality in education studies include analysing spatiality through the lens of actor networks (McGregor, 2004); explorations of the nexus between activity and spatial materiality (Reh \& Temel, 2014); studying personal and intrapersonal relations in timespace through a semiotic lens (Stables, 2014); considering FLS as an instantiation of embodied materiality (Chapman et al., 2014; McPherson \& Saltmarsh, 2017; Mulcahy \& Morrison, 2017); new materialist readings of spatiality (Charteris et al., 2017; Nelson \& Johnson, 2019); and the application of theories of networked learning (Carvalho \& Yeoman, 2018). The theoretical field is wide open to education researchers of the built environment of educational facilities, but instead there is the ready (and steady) deferral by education researchers of learning environments to approaches that privilege positivism or to qualitative research that mimics science, by developing studies primarily concerned with realist methodologies.

Education researchers may dismiss questions of 'space' as having no practical value, and thus, in their view, being irrelevant to education. This may explain why much built learning environment research fixates on establishing the measurable effects of tangible building elements on students, as if in an anxious bid to 'be relevant' and to address the question, 'where is the research?' Theorising space in relation to the manifest physical changes to the place of teaching and learning is, however, significant, for several reasons. Spatial theorising shares the qualities of critical philosophical thinking, which shakes the complacency associated with the taken-forgrantedness of everyday thinking about education. Spatial theorising can enable the learning environments researcher to make sense "of the competing rationalities underlying educational policy change, social inequality and cultural practices" (Gulson \& Symes, 2007, p. 98). Massey (1985), for whom social relations are spatial relations, argued that understanding spatial contexts is critical, as it supports the development of insights into social processes, important if one is to act on these processes politically 
(Massey, 1985). The frontiers of thinking about the current trend to developing built environments that turn the process of teaching and learning on their head are thus enlarged by theoretical considerations of space. If these suggestions are not reason enough, then add to them that raising questions about policy contradictions, political tensions, and the distribution of power and influence will lead to more interesting questions and enlightening studies (Massey, 1984/1995).

My remarks and focus in this article have centred on the built environment, notably that which has come to replace the traditional 'classroom'. Spatial theorising can, however, be applied in broader senses to education and its instantiation as facilities, too. For example, Rasmussen's (2019) study of the evolving contexts of the Danish school corridor recognises the complexity of space, deploying a materialist lens to demonstrate the evolving history of the Danish school corridor from a place of danger and discipline to a site of learning. Wood's (2019) consideration of the meeting-places over the in-betweenness and thresholds of schools highlights how thoughtful design can prompt public engagement with architecture (such as schools). Studies such as these add weight to the suggestion that 'space' is not merely an objective 'factor' to be instrumentalised and compartmentalised in the search for 'what works' in 'enhancing student achievement'. They are also a bulwark against a fetishisation of space (ie abstracting the concept and giving it special powers of causation - Wood, 2017). Further afield, the education scholar interested in advancing spatial theory could consider Lefebvre's position on 'the right to the city' that he coined in his 1968 book Le Droit à la ville, which drew attention to the reclamation of the city in the face of the increasing homogenisation and commodification associated with modern capitalism, or Soja's concept of spatial justice (2010). These concepts may be brought together to lay the foundations for theorising uneven development in education (Stewart \& Benade, 2020).

To summarise up to this point: a review of 136 original contributions to learning environments research indicated sparse evidence of robust theoretical frameworks, lenses or arguments used by their authors. The possibility of a 'spatial turn' in education research led to a substantive discussion of developments in theories of spatiality, that provided a platform for asking why space is even a relevant consideration for education researchers. Several arguments were proposed, including options for a range of approaches to spatial theorisation. What follows is my attempt to demonstrate spatial theorising in an educational policy context, by applying Lefebvre's triadic conceptualisation (1991) to the uptake of innovative educational facilities' design in New Zealand.

\section{Theoretical application}

An argument put forward in this article is that theory provides the concepts and language used to name phenomena and problems. Lefebvre's epistemological triad provides a model of analysis to apply to studies of the evolving spaces of teaching and learning. Caution is required, however, for, as Merrifield (2006) suggests, Lefebvre's heuristic triad was not intended to be a rigid framework.

For Lefebvre, spatiality is a political matter-the conceived space of planners, designers and bureaucrats (architects and Ministry of Education) is privileged above lived space. The result (argued Lefebvre) is uniform buildings aimed at the same goal, 
a suggestion that seems to be contradicted by the development of bespoke buildings, and one commissioning architects would be sure to dispute. Yet, as the policy advice in Table 2 indicates, as the bill payer, the New Zealand Ministry of Education specifies clear guidelines, that precede the potential preferences of the inhabitants and users of the designed spaces. Furthermore, the Ministry of Education has a political commitment to developing a property portfolio able to "support the needs of teachers and students into the future...[and ensuring] that our schools are fit for purpose and flexible enough to be adapted to meet future needs" (Ministry of Education, 2015, p. 3). Though architects designing educational facilities in New Zealand at present conceptualise facilities that place the inhabitants and users of the built environments at their centre, their representations of space (conceptualised space) nonetheless provide these users a guideline to convert 'thought' to 'action' (Benade, 2019a). Notably, flexibly designed space is not neutral but intentionally provides scope to shape practices of teaching and learning differently. Conceptualisations of space can shape (or create) ideology but are also shaped by ideology. Notions of $21^{\text {st }}$ century learning infuse the drive to replace the hierarchical and authoritarian, industrialised single-cell classroom. The 'cells and bells' (Nair, 2014) model of the traditional classroom and school, with its routinised rigidity could be justified in the $20^{\text {th }}$ century in terms of the ideology of industrialised capitalist development. The challenge laid down by a globalised, digital economy is how to replace or supplant industrial forms (such as schools and workplaces) with seemingly collaborative and dispersed designs, without simultaneously destroying the hierarchic and homogenised values inherent in capitalism. The remarkable buildings appearing in communities throughout New Zealand testify to the achievements of futuristic design, yet these new schools retain within themselves their prior identity-they do not destroy the fundamental feature of 'school', for example, but simultaneously propose a new imaginary, one justifying modern designs by virtue of their ability to support the development of the agile, critical, endlessly adaptable lifelong 'learner'. The ideological purpose of schools thus shifts from supporting the industrial economy to supporting the knowledge economy.

Representational spaces (or, spaces of representation) are the everyday physical spaces that are the lived reality of the users and occupants. This is the dimension of space Lefebvre believed could break the dualism of mental (conceived) and material (perceived) space. Lived spaces are associated with various symbols, images, art forms, even graffiti. The way the inhabitants and users represent this space through symbol and practice reflects their lived experience of a physical environment, in sometimes surprising ways to 'authorities'. As Lefebvre (1991) noted, while plans of routes and paths have an enduring quality, "people animate these paths and roads...through accounts of 'presences', genies and good or evil spirits" (p. 118).

Designing Schools in New Zealand - Requirements and Guidelines (DSNZ) is the key document among national guidelines for school property design. It contains advice prepared by the Ministry with input from educators, architects, engineers and quantity surveyors who work closely with schools. It is designed to give design teams a clear understanding of the Ministry's requirements and guidelines. (Ministry of Education, 2020. "Design standards and guidelines") 
Lived space is marked by certain complexities and tensions (Massey, 1992) that arise from people's sense-making, which may be reflected, for example, in the way teachers face the challenge transitioning from traditional to modern in their practice. So, teachers may be seen attempting to push back subtly and more obviously as they default to traditional practices (Benade, 2017a; 2018; Niemi, 2020; Saltmarsh et al., 2015) Transparent space encourages transparent practice, thus teachers' "practice is completely open to criticism because you see each other all the time" (reported in Benade, 2019b, p. 228). While the limitations and restrictions of the single cell classroom, often filled with standardised furniture, severely limit movement, the provision of indeterminate, flexible spaces with diverse furnishing options and wireless technology, sometimes have unintended consequences. Students, enjoying greater freedom of movement, repurpose space, 'privatising' areas as self-styled 'hideaways' or 'nooks', possibly to escape noise, or the frequent movements of people in the space (Benade, 2017a; Chapman et al., 2014).

Spatial practice is evident in the taken-for-granted physical movements of people, as they interact with the spaces of their daily lives. Whether one takes the longer, scenic route home, or elects for the faster, but uninspiring prospect of the motorway, highlights the mundane nature of daily life. Spatial practice reveals the sometimes routinised ways users and occupants of a designed environment respond to their environment. These routines may conform with the official doctrine of the conceptions of space. For instance, if a design is intended to create social space that doubles as working space, it will be expected that students, perceiving the space as having these functions, will use it accordingly (what Monahan (2002) termed, 'built pedagogy'). On the other hand, while break-out spaces may be intended to be used as places where small-group tuition can take place, they can be perceived by students as spaces of safety, or places of solitude removed from the hurly-burly of the commons. The design of FLS thus suggests certain behaviour as typical and 'appropriate', such as linking the open spaces to the invitation to collaborate.

\section{Conclusion}

This article raised the question of the significance of taking theoretical approaches to analyses of newly emerging, non-traditional, learning spaces. The question was addressed in four steps: first, setting the scene by considering a review of 136 recent original academic contributions to knowledge development in the field of learning environments research, demonstrating that robust theoretical conceptualisation is not widespread in this scholarship; second, by providing a theoretical context through a review of key developments in theorising spatiality; third, given this context, by arguing the relevance of spatial considerations to education scholarship; and finally, to illustrate Lefebvre's spatial theory by applying it to the recent development of FLS and ILE in New Zealand. Theoretical interpretations allow questions to be raised that might otherwise not be raised, thus enabling the development of new and fresh insights. That is to say, the available store of knowledge and understanding is enhanced by approaching phenomena and issues from a theoretical perspective. Theory helps to 
name experiences and phenomena, and its tools of theory enable researchers to analyse and interpret their field-based findings in fresh and surprising ways. While the approach adopted here is Lefebvrian, other examples of learning environments' analysis were suggested, indicating that a rich diversity of theoretical approaches is open to education researchers interested in studying the phenomenon of spatiality as a route to making sense of learning environments. And while the built environment was privileged in this article, my examples of alternative theoretical approaches demonstrate that 'learning environment' can also be more widely understood, opening equally rich possibilities for analysis.

The (traditional) notion of space as an abstract, objective epistemological entity only encourages empirical and mental abstractions that privilege the performance of building fabric, seeking for instance quantitative evidence on the performance of spaces and their influence on the users. This approach depoliticises space, blinding researchers to, for example, the demands of the OECD on its member states to constantly improve their education systems in the service of $21^{\text {st }}$-century skills. In contrast, taking a theoretical approach enables a critical stance, with greater emphasis on the ontological and ethical implications of space. Focussing on space and the significance of spatiality as a theoretical project has considerable merit, elevating the concept above the purely empirical or abstract, locating spatial questions in a wider socio-political context. It introduces the critical dimension of social relations and demonstrates that the issues of space are not ordered or orderly and thus do not submit to neat analyses of effects or outcomes. 


\section{References}

Alansari, M., Rubie-Davies, C. (2020). What about the tertiary climate? Reflecting on five decades of class climate research. Learning Environments Research, 23(1), 1-25. doi: https://doi.org/10.1007/s10984-019-09288-9

Baydar, G., Komesli, M., Yılmaz, A., \& Kılınç, K. (2018). Digitizing Lefebvre's spatial triad. Digital Scholarship in the Humanities, 33(1), 6-20. doi:10.1093/llc/fqw061

Benade, L. (2017a). Being a teacher in the 21st Century: A critical New Zealand study. Singapore: Springer Nature. Available Springer online https://link.springer.com/book/10.1007\%2F978-981-10-3782-5

Benade, L. (2017b). Is the classroom obsolete in the twenty-first century? Educational Philosophy and Theory, 49(8), 796-807. doi:10.1080/00131857.2016.1269631

Benade, L., Bertelsen, E. \& Lewis, L. (2018). Reimagining and reshaping spaces of learning: Constituting innovative and creative lifelong learners. In L. Benade \& M. Jackson (Eds.), Transforming education: Design \& governance in global contexts (pp. 33-54). Singapore: Springer Nature. doi: https://doi.org/10.1007/978-981-10-5678-9 3

Benade, L. (2019a). Innovative educational facilities' design: Why it matters to education and educators. In M.A. Peters (Ed.), Encyclopedia of Teacher Education. Springer, Singapore, https://doi.org/10.1007/978-981-13-1179-6

Benade, L. (2019b). Pedagogy in flexible learning spaces. In M. Hill and M. Thrupp (Eds.). The professional practice of teaching in New Zealand (6th ed). (pp. 213-235). Melbourne, Australia: Cengage

Blackmore, J., Bateman, D., Loughlin, J., O'Mara, J., \& Aranda, G. (2011). Research into the connection between built learning spaces and student outcomes: Literature Review. Victorian Department of Education and Early Childhood Development. Retrieved from https://www.eduweb.vic.gov.au/edulibrary/public/publ/research/publ/blackmore learni ng spaces.pdf.

Byers, T; Imms, W; \& Hartnell-Young, E. (2018). Evaluating teacher and student spatial transition from a traditional classroom to an innovative learning environment. Studies in Educational Evaluation, 58, 156-166. https://doi.org/10.1016/i.stueduc.2018.07.004

Campbell, L. (2020). Teaching in an inspiring learning space: An investigation of the extent to which one school's innovative learning environment has impacted on teachers' pedagogy and practice. Research Papers in Education, 35(2), 185204, doi: $10.1080 / 02671522.2019 .1568526$

Carvalho, L. \& Yeoman, P. (2018). Framing learning entanglement in innovative learning spaces: Connecting theory, design and practice. British Educational Research Journal, 44(6), 1120-1137. doi: 10.1002/berj.3483

Chapman, A., Randell-Moon, H., Campbell, M., \& Drew, C. (2014). Students in space: Student practices in non-traditional classrooms. Global Studies of Childhood, 4(1), 39-48. doi:10.2304/ gsch.2014.4.1.39

Charteris, J., \& Smardon, D. (2018). "Professional learning on steroids": Implications for teacher learning through spatialised practice in New Generation Learning Environments. Australian Journal of Teacher Education, 43(12). doi: http://dx.doi.org/10.14221/ajte.2018v43n12.2

Charteris, J., \& Smardon, D. (2019). Dimensions of agency in New Generation Learning Spaces: Developing assessment capability. Australian Journal of Teacher Education, 44(7). doi: http://dx.doi.org/10.14221/ajte.2019v44n7.1

Charteris, J., Smardon, D., \& Nelson, E. (2017). Innovative learning environments and new materialism: A conjunctural analysis of pedagogic spaces. Educational Philosophy and Theory, 49(8), 808-821, doi: 10.1080/00131857.2017.1298035

Daniels, H., Tse, H. M., Stables, A., \& Cox, S. (2017). Design as a social practice: The design of new build schools. Oxford Review of Education, 43(6), 767-787. doi: https://doi.org/10.1080/03054985.2017.1360176 
Elden, S. (2004a) Between Marx and Heidegger: Politics, philosophy and Lefebvre's The Production of Space. Antipode, 34(1), 86-105.

Elden, S. (2004b). Understanding Henri Lefebvre. Continuum.

Foucault, M. (2008). Of other spaces: Utopias and heterotopias (L. De Cauter \& M. Dehaene, Trans.). In M. Dehaene \& L. De Cauter (Eds.), Heterotopia and the city: Public space in a postcivil society (pp. 13-29). Routledge.

Gulson, K.N. \& Symes, C. (2007). Knowing one's place: space, theory, education. Critical Studies in Education, 48(1), 97-110, doi: 10.1080/17508480601123750

Hipkins, C. (2018). Towards a comprehensive reform of school property. Cabinet Paper. Retrieved 18 April 2020 from https://www.education.govt.nz/our-work/informationreleases/issue-specific-releases/cabinet-paper-towards-a-comprehensive-reform-ofschool-property/

Imms, W. (2016). New generation leaning environments: How can we find out if what works is working? In W. Imms, B. Cleveland \& K. Fisher (Eds.), Evaluating learning environments, pp. 21-34. Rotterdam, The Netherlands: Sense Publishers

Imms, B. Cleveland \& K. Fisher (Eds.). (2016). Evaluating learning environments. Rotterdam, The Netherlands: Sense Publishers

Jenlink, P.M. (2007). Creating public spaces and practiced places for democracy, discourse, and the emergence of civil society. Systemic Practice and Action Research, 20(5). 429-440 https://doi.org/10.1007/s11213-007-9077-1

Krueger, P. (2010). It's not just a method! The epistemic and political work of young people's lifeworlds at the school-prison nexus, Race Ethnicity and Education, 13(3), 383-408, doi: $10.1080 / 13613324.2010 .500846$

McGregor, J. (2004). Spatiality and the place of the material in schools. Pedagogy, Culture and Society, 12(3), 347-372.

Massey, D. (1984/1995). Spatial divisions of labour: Social structures and the geography of production ( $2^{\text {nd }}$ ed.). Macmillan.

Massey, D. (1985). New directions in space. In D. Gregory \& J. Urry (Eds.), Social relations and spatial structures (pp. 9-19). Macmillan.

Massey, D. (1992). Politics and space/time. New Left Review, 192, 65-84.

McPherson, A., \& Saltmarsh , S. (2017). Bodies and affect in non-traditional learning spaces. Educational Philosophy and Theory, 49(8), 832-841. doi: https://doi.org/10.1080/00131857.2016.1252904

Merrifield, A. (2006). Henri Lefebvre: A critical introduction. Taylor \& Francis Group.

Ministry of Education. (2011). The New Zealand school property strategy 2011-2021. Wellington, New Zealand: Author. Available at http://gdsindexnz.org/wpcontent/uploads/2015/10/The-New-Zealand-School-Property-Strategy-2011-2021.pdf

Ministry of Education. (2015). Designing schools in New Zealand: Requirements and Guidelines. Wellington, New Zealand: Author. Available at http://www.education.govt.nz/assets/Documents/Primary-

Secondary/Property/Design/Design-guidance/DSNZ-version-1-0-20151014.pdf

Ministry of Education. (2020). Designing learning environments. Wellington, New Zealand: Author. Available at http://www.education.govt.nz/school/property-andtransport/projects-and-design/design/designing-learning-environments/\#relationship

Monahan, T. (2002). Flexible space \& built pedagogy: Emerging IT embodiments. Inventio, 4(1), 1-19. https://publicsurveillance.com/papers/built pedagogy.pdf

Mulcahy, D. \& Morrison, C. (2017). Re/assembling 'innovative' learning environments: Affective practice and its politics. Educational Philosophy and Theory, 49(8), 749758, doi: $10.1080 / 00131857.2016 .1278354$

Nair, P. (2014). Blueprint for tomorrow: Redesigning schools for student-centered learning. Cambridge, MA: Harvard Education Press.

Nelson, E., \& Johnson, L. (2019). ILEs as social assemblages: Implications for initial teacher education. In W. Imms \& M. Mahat. (Eds.), Proceedings of the international symposium: Transitions19 One journey, many pathways (pp. 8998). Retrieved from https://minerva- 
access.unimelb.edu.au/bitstream/handle/11343/237432/Transitions2019 web.pdf?se quence $=1$ \&isAllowed $=y$

Newton, C. (2009). Disciplinary dilemmas: Learning spaces as a discussion between designers and educators. Critical \& Creative Thinking, 17(2), 7-27. Available at http://hdl.handle.net/11343/192320

Niemi, K. (2020). 'The best guess for the future?' Teachers' adaptation to open and flexible learning environments in Finland. Education Inquiry [Early online]. doi: $10.1080 / 20004508.2020 .1816371$

Rasmussen, L.R. (2019). Disassembling the in-between? Refigurations of the Danish school corridor 1950-2019. Paedagogica Historica, doi: 10.1080/00309230.2019.1669680. https://doi.org/10.1080/00309230.2019.1669680

Reh, S., \& Temel, R. (2014). Observing the doings of built spaces. Attempts of an ethnography of materiality. Historical Social Research, 39(2), 167-180 doi:10.12759/hsr.39.2014.2.167-180

Saltmarsh, S., Chapman, A., Campbell, M., \& Drew, C. (2015). Putting "structure within the space": Spatially un/responsive pedagogic practices in open-plan learning environments. Educational Review, 67(3), 315-327.

Sigurðardóttir, A. K., \& Hjartarson, T. (2016). The idea and reality of an innovative school: From inventive design to established practice in a new school building. Improving Schools, 19(1), 62-79. doi: https://doi.org/10.1177\%2F1365480215612173

Sigurðardóttir A.K., \& Hjartarson T. (2018). Design features of Icelandic school buildings: How do they reflect changes in educational governance and daily school practice?. In: I. Grosvenor, L. Rosén Rasmussen (Eds). Making education: Material school design and educational governance, pp. 71-91. Springer

Smith, N. (1990). Uneven development: Nature, capital and the production of space. Blackwell.

Soja, E.W. (1985). The spatiality of social life: Towards a transformative retheorisation. In D. Gregory \& J. Urry (Eds.), Social relations and spatial structures (pp. 90-127). Macmillan.

Soja, E.W. (1989). Postmodern geographies: The reassertion of space in critical social theory. Verso

Soja, E. (2010). Seeking spatial justice. University of Minnesota Press.

Stables, A. (2014). The semiotics of organisational landscape: School as design. I. S. A. Semetsky (Ed.), Edusemiotics (pp. 116-127). Taylor and Francis.

Stewart, G., \& Benade, L. (2020). Spatial biculturalism for schools in Aotearoa New Zealand. New Zealand Journal of Educational Studies, 55(1). 129-131. doi: https://doi.org/10.1007/s40841-020-00169-x

Watkins, C. (2005). Representations of space, spatial practices and spaces of representation: An application of Lefebvre's spatial triad. Culture and Organization, 11(3), 209220, doi: $10.1080 / 14759550500203318$

Wood, A. (2017). A school's lived architecture: the politics and ethics of flexible learning spaces [Doctoral thesis, Manchester Metropolitan University]. e-space Manchester Metropolitan University's Research Repository. https://e-space.mmu.ac.uk/618818/

Wood, A. (2019, June 10). City schools as meeting places [Webblog]. https://architectureandeducation.org/2019/06/10/city-schools-as-meeting-places/ 